\title{
Anti-Ri autoimmune encephalitis associated with breast cancer
}

\author{
Encefalite autoimune Anti-Ri associada a câncer de mama \\ Euripedes Gomes de CARVALHO NETO', Matheus Ferreira GOMES', Ronnie Peterson Marcondes ALVES², \\ Alexei Peter dos SANTOS ${ }^{3}$, Cristiano BRUM4 , Ricardo SANTIN ${ }^{1}$
}

A 73-year-old woman with breast cancer presented with asthenia, lethargy and imbalance, followed by bilateral ptosis and ophthalmoparesis. There was progression to tetraparesis. Magnetic resonance imaging (MRI) of the brain was performed (Figure 1). Cerebrospinal fluid (CSF) showed six leukocytes (with predominance of lymphocytes). The Anti-Ri neuronal antibody was positive. The patient presented respiratory distress, requiring orotracheal intubation. Despite pulse therapy and intravenous immunoglobulin, she presented systemic worsening and died.

Anti-Ri antibodies can produce heterogeneous paraneoplastic neurological syndrome. Involvement of the brainstem can lead to ophthalmoplegia, truncal ataxia, opsoclonus-myoclonus syndrome, and decreased central respiratory drive. Anti-Ri encephalitis requires extensive and urgent investigation of the underlying tumor whose treatment is imperative $e^{1,2,3,4}$.

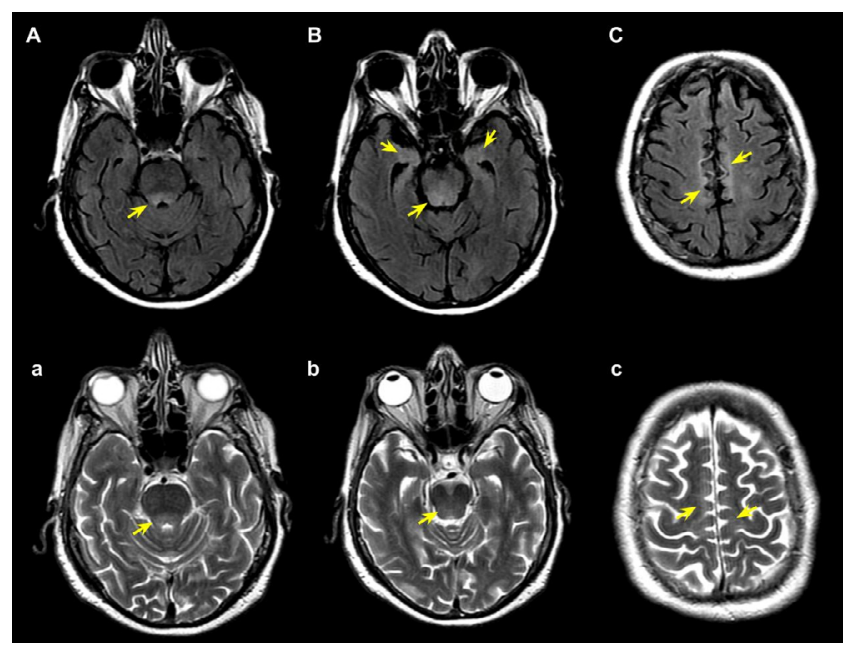

Figure 1. Magnetic resonance imaging of the brain. Axial fluidattenuated inversion recovery (A, B, and C) and T2 weighted ( $a, b$, and c) images showing areas of signal hyperintensity involving formations of the pontine tegmentum in the bulbar region (A, a, $\mathrm{B}$, and b), periaqueductal gray region, and mesial temporal lobes, including the hippocampus (B) and the subcortical region of the superior frontal gyrus extending to the paracentral lobe ( $\mathrm{C}$ and $\mathrm{c}$ ).

\section{References}

\footnotetext{
1. Tay JK, Miller J, Joshi A, Athey RJ. Anti-Ri-associated paraneoplastic cerebellar and brainstem degenerative syndrome. J R Coll Physicians Edinb. 2012;42(3):221-4. https://doi.org/10.4997/ JRCPE.2012.307

2. Kim H, Lim Y, Kim K. Anti-Ri-antibody-associated paraneoplastic syndrome in a man with breast cancer showing a reversible pontine lesion on MRI. J Clin Neurol. 2009 Sep;5(3):151-2. https://doi. org/10.3988/jcn.2009.5.3.151
}

3. Murphy BL, Zalewski NL, Degnim AC, McKeon A, Flanagan EP, Pittock SJ, et al. Breast cancer-related paraneoplastic neurologic disease. Breast Cancer Res Treat. 2018 Feb;167(3):771-8. https://doi. org/10.1007/s10549-017-4566-0

4. Butt R, Vatandoust S, Kleinig T, Adams J, Basu S, Otto G, et al. Anti-Ri antibody-associated paraneoplastic brainstem encephalitis successfully treated after treating the underlying malignancy with letrozole. Intern Med J. 2013 May;43(5):605-6. https://doi.org/10.1111/imj.12123

\footnotetext{
IIrmandade da Santa Casa de Misericórdia de Porto Alegre, Departamento de Neurologia, Porto Alegre RS, Brazil. 2Irmandade da Santa Casa de Misericórdia de Porto Alegre, Departamento de Radiologia, Porto Alegre RS, Brazil. ${ }^{3}$ Irmandade da Santa Casa de Misericórdia de Porto Alegre, Departamento de Oncologia Clínica, Porto Alegre RS, Brazil. ${ }^{4}$ Irmandade da Santa Casa de Misericórdia de Porto Alegre, Departamento de Psiquiatria, Porto Alegre RS, Brazil.

Euripedes Gomes de CARVALHO NETO (iD https://orcid.org/0000-0002-5124-7877; Matheus Ferreira GOMES (ID) https://orcid.org/0000-0002-4762-4510; Ronnie Peterson Marcondes ALVES (D) https://orcid.org/0000-0002-9369-1917; Alexei Peter dos SANTOS (D) https://orcid.org/0000-0002-4012-1267; Cristiano BRUM (iD https://orcid.org/0000-0003-4329-6756; Ricardo SANTIN (iD https://orcid.org/0000-0002-7835-3514

Correspondence: Euripedes Gomes de Carvalho Neto; E-mail: euripedescneto@gmail.com

Conflict of interest: There is no conflict of interest to declare.

Authors' contributions: EGCN, MFG, RPMA, APS and CB: data acquisition and literature review. RS: critical revision of the manuscript for intellectual content and study supervision.

Received on May 19, 2020; Received in its final form on June 10, 2020; Accepted on June 15, 2020.
} 